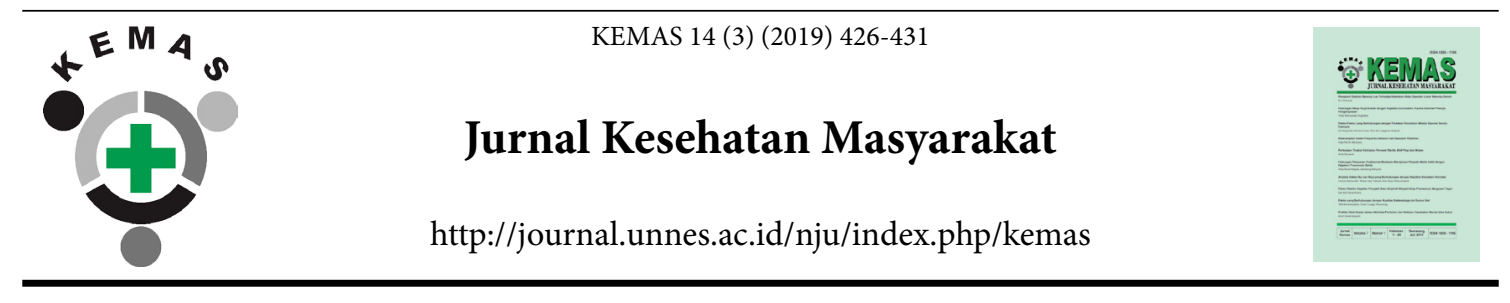

\title{
The Effectiveness of 8 Weeks Low Impact Aerobics and Yoga Combination Program on Body Fat Percentage among Obese Female
}

\author{
Roy Januardi $\operatorname{Irawan}^{1 \bowtie}$, Mirwa Adiprahara Anggarani² \\ ${ }^{1}$ Jurusan Pendidikan Kesehatan dan Rekreasi, Fakultas Ilmu Olahraga, Universitas Negeri Surabaya \\ ${ }_{2}^{2} J u r u s a n$ Kimia, Fakultas Matematika dan Ilmu Pengetahuan Alam, Universitas Negeri Surabaya
}

\begin{tabular}{l} 
Article Info \\
\hline Article History: \\
Submitted March 2018 \\
Accepted May 2018 \\
Published March 2019 \\
\hline Keywords: \\
BMI, obese, yoga, \\
aerobics, anthropometry \\
\hline DOI \\
https://doi.org/10.15294/ \\
kemas.v14i3.13780
\end{tabular}

\begin{abstract}
The prevalence of obesity of adult women in Indonesia has increased recently. Obesity among adult women will lead to health problems such as diabetes until coronary heart disease. The aim of this quasy experimental study was to determine the effectiveness of the 8-week exercise program combining low impact aerobics and yoga on the percentage of body fat in women in 2017. The subjects of this study were 12 Unesa female studentss with criteria to have Body Mass Index (BMI) obese category with age 19-24 years. The effectiveness of the 8-week low-impact exercise program of aerobics and yoga on the percentage of body fat was measured using anthropometric methods with skinfold caliper techniques measured before and after the treatment of training programs. Based on the results of calculations using $t$ test on the percentage of body fat then 8-week exercise program combination of low impact aerobics and yoga effective in reducing body fat with an average percentage decreased of $10.56 \%$.
\end{abstract}

\section{Introduction}

Women obesity prevalence in Indonesia has increased year after year. The Basic Health Research result (Riset Kesehatan Dasar/Riskesdas, 2013) showed the prevalence of mature women obesity ( $>18$ years old) was $32.9 \%$, which was increase $18.1 \%$ from 2007 (13.9\%) and $17.5 \%$ from 2010 (15.5\%). This mean 3 of 10 women in Indonesia was obese, and there could be a chance of annual increase. This make Indonesia would be vulnerable in future health (Peltzer \& Pengpid, 2013). Obesity is a disorder marked with excessive fat staging under the skin and sometime reached to internal organs. WHO (2014), stated a limit that woman with Body Mass Index (BMI) above 25 was cathegorized as overweight while woman with BMI above 30 was obese.

Obesity is a condition of over body weight yet on the same time there is excessive body fat accumulation. The obesity whether patologic or physiologic caused by excessive food intake resulting the metabolic problem. Obesity is caused by many factors include genetic, environment, metabolism, endochrene function change, excessive fat, life style and meal habit, medicine caused and gastronomic problem (Xia, 2013). Other cause is the increase of cortisol secression. Mukarommah (2016), also mentioned that high cortisol could resulted in obesity.

Someone can be cathegorized as obesity by measure the body fat composition percentage. Williams (2010), said a woman with 
body fat percentage above $30 \%$ is cathegorized as obese. The Physical Anthropometric Measurement method using Skinfold Caliper is one of the method to determine body fat composition. Supriarsa (2001), mentioned the physical anthropometric measurement method is the most often to be used. The measurement method commonly adopted is Jackson Pollock reference.

Obese person has the risk of severe disease infection. WHO (2014) stated the obesity could initiate various disease such as diabetes, cardiovascular disease, musculosceletal disorder and several kind of cancer. Pengpid (2013) explained the obesity is caused by poor daily physical activity. The determination of dietary menu and life style also contribute the obesity on woman.

The method can be used to decrease body weight for obese person such as aerobic gymnastic. Sugiarti (2008) concluded there is effect of one month aerobic gymnastic to the body weight decrease with average $0.34 \mathrm{~kg}$ for women joining the program at Kartika Gym. Sugiarti (2008) also mentioned combination between body language and aerobic gymnastic contribute higher average body weight reduction which was $1.32 \mathrm{~kg}$ a month. Sientia (2012) explained there was body weight decrease of aerobic gymnastic member on a gym after 12 weeks with average decrease 2.89 $\mathrm{kg}$ or $4.7 \%$.

Beside by aerobic gymnastic, other method used to reduce body weight is yoga. Hidayanti (2015), explained yoga exercise is effective to reduce abdominal circumference and BMI. Other study mentioned Kapha Yoga method and Vinyasa Yoga are effective to reduce body fat. Kapha Yoga method decreased average BMI to 3.28 on high lunge capacity, as for low lunge capacity was 2.26. Meanwhile by Vinyasha Yoga average BMI decreased to 8.04 on high lunge capacity, as for low lunge capacity was 5.36 . Therefore can be concluded that Vinyasha Yoga method is better to reduce BMI (Panggraita, 2017).

One of the ways to reduce body weight as well as body fat percentage for obese person is by doing physical activity. The High Impact Aerobic beside hard to do also contains injury risk so that reduce obese person interest. Yoga, on the other side is a physical exercise and on the same time train the athele psychologically, which nowadays become an alternative to reduce body height as well as body fat percentage for obese person (Kusuma, 2017). Therefore in this research an 8 weeks exercise program combining low impact aerobic and yoga was offered to reduce body fat percentage as one of obesity parameter. The objective of this research is to find out the effectiveness of 8 weeks low impact aerobics and yoga combination program on body fat percentage among obese female.

\section{Method}

This reseach is a quantitative research with quasy experimental design by pre-post approach to find out the effectiveness of 8 weeks low impact aerobics and yoga combination program. This research was conducted at Unesa campus on September - October 2017. The subject in this research was Unesa female students, aged 19-24 years old. The incusion criteria were willing to join exercise program for consecutive 8 months, had obesity cathegorized BMI, willing to be taken the anthropometric data and willing to fill the informed consent. While the exclusion criteria were on diet program, on medicine therapy and on sick condition.

The date in this research were primary data consisted of age, height and weight. Fat percentage data obtained through skinfold caliper measurement. Budiman (2008) conducted validation to this technique and concluded it has proper validity as fat percentage measurement.

The fat percentage data was obtained from anthropometric measurement by skinfold caliper method taken from skin folds on abdomen, thigh, triceps and suprailiac. Body fat percentage then calculated used Jackson Pollock method. The formula is as below:

$\%$ Fat $=(.29669)($ sum of 4 skinfolds $)-(.00043)$ $($ Sum of four skinfolds squared $)+.02963($ age $)+$ 1.4072

Fat percentage data of the subjects were taken on pre test and post test. The subjects were involved in a program of low impact aerobics and yoga combination. The exercise took 3 
times a week for 8 weeks at Unesa campus.

Data of fat percentage taken on pre test and post test then be analyzed by Mann Whitney test to compare before and after treatment and previously had been through normality and homogenity test. All statistic tests were conducted on SPSS software.

\section{Result and Discussion}

Based on inclusion and inclusion criteria 12 Unesa female studentss were obtained as participants in this research. Before the treatment, the subjects went through anthropmetric measurement as pre test data then the subjects took 8 weeks low impact aerobics and yoga combination program, after that the anthropometric measurement was conducted again as post test data.

The research subjects were active student listed on Surabaya State University. Based on table 1 can be seen the characteristics as follow: average age was 21.33 years old $( \pm 1.37)$, average body weight $73.04 \mathrm{~kg}( \pm 6.37)$, average body height $1.53 \mathrm{~m}( \pm 0.05)$, and average BMI 30.82 $( \pm 0.79)$. Based on minimum BMI 30 , then all the subjects are cathegorized as obesity.

Based on table 1, can be seen that average thickness of abnominal fat was 36.5 $\mathrm{mm}( \pm 3.5)$, average thickness of thigh fat was $33.2 \mathrm{~mm}( \pm 3.3)$, average thickness of triceps fat was $32.9 \mathrm{~mm}( \pm 2.1)$, average thickness of suprailiac fat was $31.7 \mathrm{~mm}( \pm 3.6)$. Thus average fat percentage was $34.1 \%( \pm 2.1)$. Therefore all subjects could be cathegorized as obesity.

Based on Table 1, after 8 weeks low impact aerobics and yoga combination program the average thickness of abdominal fat was 31.5 $\mathrm{mm}( \pm 3.5)$, average thickness of thigh fat was $28.5 \mathrm{~mm}( \pm 3.3)$, average thickness of triceps fat was $28 \mathrm{~mm}( \pm 2.2)$, average thickness of suprailiac fat was $27.3 \mathrm{~mm}( \pm 3,8)$, thus average fat percentage was $30.5 \%( \pm 2.2)$ therefore all subjects could be cathegorized as obesity.

Measurement result of average anthropometric on abdomen, thigh, triceps, dan suprailiac (Jackson Pollock technique) when pretest and posttest is presented in picture 1 :

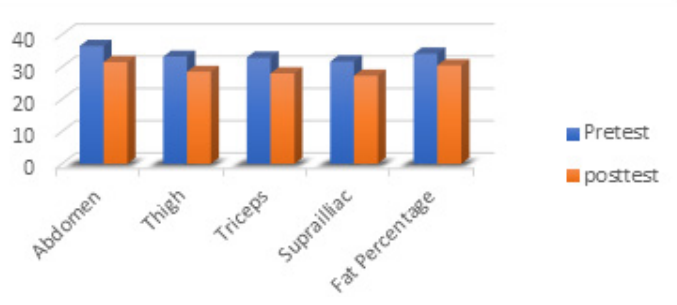

Picture 1. Anthropometric Measurement Result of Pretest and Posttes

Table 1. Subject Characteristic and Anthropometric Measurement Result (Pretest \& Posttest)

\begin{tabular}{llllll}
\hline Characteristics & $\mathrm{n}$ & Min & Max & Mean & SD \\
\hline Age (years) & 12 & 19 & 24 & 21.33 & 1.37 \\
Weight (Kg) & 12 & 64.8 & 88.10 & 73.04 & 6.37 \\
Height (m) & 12 & 1.47 & 1.65 & 1.53 & 0.05 \\
Body Mass Index & 12 & 30 & 32.30 & 30.82 & 0.79 \\
\hline Component & $\mathrm{n}$ & Min & Max & Mean & SD \\
\hline Abdomen (mm) & 12 & 31 & 42 & 36.5 & 3.5 \\
Thigh (mm) & 12 & 28 & 38 & 33.2 & 3.3 \\
triceps (mm) & 12 & 30 & 37 & 32.9 & 2.1 \\
Suprailiac (mm) & 12 & 27 & 38 & 31.7 & 3.6 \\
Fat Percentage (\%) & 12 & 31.6 & 37.4 & 34.1 & 2.1 \\
\hline Abdomen (mm) & 12 & 27 & 38 & 31.5 & 3.5 \\
Thigh (mm) & 12 & 24 & 33 & 28.5 & 3.3 \\
triceps (mm) & 12 & 25 & 32 & 28 & 2.3 \\
Suprailiac (mm) & 12 & 23 & 34 & 27.3 & 3.8 \\
Fat Percentage (\%) & 12 & 28.2 & 34.5 & 30.5 & 2.2 \\
\hline Source Primary Data & & & &
\end{tabular}

Source: Primary Data 
The normality and homogenity test on fat percentage data of pretest and postest were required to determine hypothesis test would be chosen. From Shapiro - Wilk normality test, the pre test $p$ value was 0.122 and $p$ post test $p$ value was 0.034 . Both were higher than 0.05 so the data was normally distributed (table 2).

Based on homogenity test result by Bartlet technique and SPSS Lavene test both fat percentage data, pre test as well as post test, were homogen since the $p$ value $0.696>0.05$.

Hypothesis test used was paired sample test to identify the difference on fat percentage before and after 8 weeks low impact aerobics and yoga combination program treatment. The result was sig value (2-tailed) $0.000<0.05$ (table 2), and since then can be concluded that the program is effective to reduce body fat. It can also be seen that average decrease of obese women body fat percentage was from 34.1\% to $30.5 \%$. Yet this body fat percentage was still cathegorizedas obesity.

The body fat percentage decrease on the subjects was result of physical activity given for consecutive 8 weeks through low impact aerobics and yoga combination program. Perform the aerobic training within long period like walking, jogging, climbing, swimming, aerobic gymnastic and yoga can burn fat and reducing body weight. Aerobic gymnastic could improve blood circulation and oxygen transmission capacity, as well as body metabolism (Sheng, 2015).

The change on body weight is caused by consumed food intake compare to energy consumption. Several studies concluded when low physical activity combine with high food consumption then the body weight will increase. Some researches concluded that physical activity conducted will prevent body weight increase (Swift, 2011). Based on it, then physical activity like programmed aerobic gymnastic and yoga can burn body fat as so the body weight will be maintained. American College of Sports Medicine (Donelly, 2009) recommended moderate to high physical activity for 150-250 minutes per week to burn $1500-2500 \mathrm{kcal}$.

Obesity is a fat staging condition above normal standard as result of imbalance food consumption and energy consumed. Food does not be used as energy will be conserved in adipose tissue as energy reserve in form of triglyceride. When body need energy then the triglyceride reserve in the adipose tissue will be parsed to energy. Aerobic workout activity performed in long duration will parse more triglyceride to energy, so that reduce fat conserved under adipose (Munawarrah, 2011).

8 weeks low impact aerobics and yoga combination program routinely joined by obese Unesa female students is a physical activity able to increase fat metabolism so that conserved fat can be conversed into energy. Fat acid conserved will be conversed into ATP (Adenosine Triphosphat) through beta oxidation. The number of ATP produced in beta oxidation process rely on C (Carbon) atom and can only produce energy under sufficient $\mathrm{O}_{2}$ supply. The fat acid burning into $\mathrm{CO}_{2}$ and $\mathrm{H}_{2} \mathrm{O}$ is taken place in the Mitochondria which is ATP generation place from electron transmission from fat acid to oxygen (Indra, 2007). The Beta Oxidation process requires carbohydrate to completely burn fat acid into asetyl-KoA and then enter the krebs cycle to become energy. Aerobic workout will trigger fat oxidation and fat supply as energy source, thus increase fat metabolism capacity. Beside, it will be followed by the increase of enzimes activity also fat acid activation, transportation and parsing (Indra, 2007).

Table 2. Normality Test of Pre Test and Post Test Fat Percentage by Shapiro-Wilk Method

\begin{tabular}{lllllll}
\hline \multicolumn{7}{l}{ Tests of Normality } \\
& \multicolumn{7}{l}{ Kolmogorov-Smirnova } & \multicolumn{7}{l}{ Shapiro-Wilk } \\
\cline { 2 - 8 } & Statistic & df & Sig. & Statistic & df & Sig. \\
\hline FatPerc1 & .180 & 12 & $.200^{*}$ & .891 & 12 & .122 \\
FatPerc2 & .257 & 12 & .028 & .847 & 12 & .034 \\
\hline
\end{tabular}

*. This is a lower bound of the true significance.

a. Lilliefors Significance Correction 
On the beginning of exercise, fat acid concentration in blood will decrease due to fat acid increase by active muscle. Further exercise activity will increase fat acid release from lipid tissue. This is caused by the hormones (ephineprine, glucagon and cortisol parse adipose tissue into triglycerid) driven by sympathetic nerve system and result of insuline hormone decrease during the exercise. The low and medium intensity exercise with long duration use triglyceride as energy. The intramuscular and plasma triglyceride formed from fat oxidation result will be used as energy source during muscle contraction.

On the beginning of exercise the energy obtained from carbohydrate and fat is equal, then gradually increase the fat usage as energy source during the exercise taken time for an hour or more when the carbohydrate usage decrease, since when the usage of triglyceride as energy, blood sugar decrease follows by insuline decrease and glucagon increase (Munawarroh, 2011). The beta oxydation process (fat acid breaking into ATP process) will provide energy (ATP) required during aerobic exercise. The aerobic exercise like yoga and aerobic gymnastic in long duration will release more conserved fat acid into ATP as energy source for aerobic exercise activity.

The reduction of fat thickness on particular area like abdomen, thigh, tricep and suprailiac also caused by yoga moves. Rshikesan (2016), explained that yoga give effect of fat thickness reduction on several points (Cumulative Skin Fold Thickness). Based on previous initial studies, the 8 weeks low impact aerobics and yoga combination program is considered effective to reduce body fat percentage on female.

\section{Conclussion}

Beside the meal habit, the lack of physical activity become one of the reason of obesity. The anthropometric measurement by skinfold caliper is a proper instrument to find out fat percentage in order to determine obesity level. Aerobic based physical activity like aerobic gymnastic, jogging, walking and yoga conducted regularly with certain duration can increase fat metabolism into energy source. Therefore 8 weeks low impact aerobics and yoga combination program regularly conducted is effective to reduce fat percentage for obesity persons with average $10.56 \%$.

\section{Reference}

Budiman, I., 2008. Validitas Pengukuran Lemak Tubuh yang Menggunakan Skinfold Caliper di 2, 3, 4, 7 Tempat terhadap Cara Bod Pod. Maranatha Journal of Medicine and Health, 7(02), pp. 1-12

Donnelly, J.E., Blair, S.N., \& Jakicic, J.M., 2009. Appropriate Physical Activity Intervention Strategies for Weight Loss and Prevention of Weight Regain for Adults. Med Sci Sports Exerc, 2009(41), pp. 459-71.

Hidayanti, N., 2015. Pengaruh Latihan Yoga Terhadap Obesitas pada Ibu-Ibu di Desa Karang Tengah Nogotirto Gamping Sleman Yogyakarta. Naskah Publikasi. Stikes Aisyiyah Yogyakarta, pp. 1-16.

Indra, E.N., 2007. Kontribusi Latihan pada Metabolisme Lemak. Jurnal Medikora, 3(1), pp. $42-60$.

Kusuma, D.A., \& Bin, W., 2017. Effect of Yoga Program on Mental Health: Competitive Anxiety in Semarang Badminton Athletes. Jurnal Kesehatan Masyarakat, 13(1), pp. 121130

Mukarommah, S.B., Susanto H., \& Rahayu, T., 2016. Effect of Aquarobic And Weight Training on Cortisol Levels in Obese Women. Jurnal Kesehatan Masyarakat, 2(1), pp. 34-42

Munawarrah, M., 2011. Penambahan Pelatihan Kekuatan Otot Pada Pelatihan Interval Menurunkan Trigliserida Mahasiswi Gemuk Universitas Esa Unggul. Jurnal Fisioterapi, 11(1), pp. $36-55$.

Panggraita, GN, Sugiharto, Soenyoto, T., 2017. Pengaruh Latihan Hatha Yoga dan Kapasitas Vital Paru Terhadap Penurunan Lemak Tubuh. Jurnal Physical education and Sports (JPES), 6(1), pp. 29-35.

Peltzer, K., Pengpid, S., 2013. Subjective Happiness and Health Behavior Among A Sample of University Students in India. Social Behavior and Personality: An International Journal, 41, pp. 1045-1056.

Riskesdas., 2013, Riset Kesehatan Dasar (Riskesdas 2013), Kementrian Kesehatan Republik Indonesia, Jakarta

Rshikesan, Subramanya, P., \& Nidhi, R., 2016. Yoga Practice for Reducing the Male Obesity and Weight Related Psychological Difficulties-A Randomized Controlled Trial. Journal of Clinical and Diagnostic Research, 10(11), pp. OC22-OC28

Sientia, F., 2012. Pengaruh Latihan Senam Aerobik Terhadap Perubahan Berat Badan Pada 
Peserta Klub Kebugaran. Jurnal Media Medika Muda, 1(1), pp. 1-17

Sheng, M., 2015. Effect of Aerobic Exercise on the Maximum Oxygen Uptake of Obese College Students. Tech Pract Fight, 10, pp. 12-13.

Sugiarti, N., \& Noor, Z., 2008. The Influence of Ordinary (Aerobic Exercise) and Special Sport Program (Body Language and Aerobic Exercise) on Weight Loss. Jurnal Mutiara Medika, 8(1), pp. 01-08.

Damon L. Swift., Neil, M. Johannsen., Carl, J. Lavie., Conrad, P. Earnest., \& Timothy, S. Church., 2011. The Role of Exercise and Physical Activity in Weight Loss and Maintenance.
HHS Public Manuscript. Prog Cardiovasc Dis, 56(4), pp. 441-447.

WHO., 2014. About Cardiovascular Diseases. World Health Organization. Geneva.

Williams, R.D., Barnes, J.T., \& Pujol T.J., 2010. Comparison of Body Composition Assessment Techniques in a Non-Athletic, Non-Obese Young Adult Population. Journal of Strength and Conditioning Research, 24(1), pp. 1-10.

Xia, Y., 2013. Effects of Exercise on the Body Morphology and Heart Rate of Obese Female College Students. Journal Dalian Univ, 34, pp. 101-103. 